\title{
Quantum chemical designing of cholesterol containing radionuclide anticancer agents
}

\author{
E.A.Dikusar ${ }^{1}$, V.M.Zelenkovskii ${ }^{1}$, A.L.Pushkarchuk ${ }^{1}$,

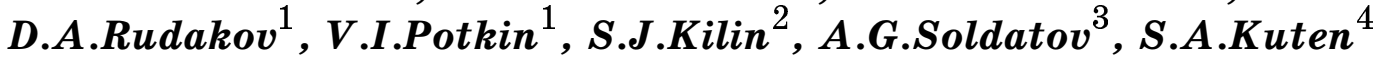 \\ ${ }^{1}$ Institute of Physical Organic Chemistry, National Academy of Sciences of \\ Belarus, 13 Surganova Str., 220072 Minsk, Belarus \\ ${ }^{2}$ B. Stepanov Institute of Physic, National Academy of Sciences of \\ Belarus, 68 Prosp. Nezavisimosti, 220072 Minsk, Belarus \\ ${ }^{3}$ Scientific and Practical Materials Research Center, National Academy of \\ Sciences of Belarus, 19 P.Brovka Str., 220072 Minsk, Belarus \\ ${ }^{4}$ Research Institute for Nuclear Problems of Belarusian State University, \\ 11 Bobruiskaya Str., 220030 Minsk, Belarus
}

Received December 18, 2015

In this work DFT simulation of the electron structure of cholesterol containing radionuclide agents (cluster systems of carborane (ortho-1, meta-2, para-3) and fullerenol derivatives) for oncological diseases therapy was carried out. Cluster systems of endohedral backminsterfullerenol $C_{60}$ derivatives have a promise perspectives in medical application as radionuclide (Fe 10a, $Y$ 10b, Re 10c, Po 10d, Rn 10e isotope contained) nanosized anticancer agents. According to the cluster stability data obtained by the DFT calculation there is a possibility of their real practical obtainment.

Keywords: cholesterol, radionuclide agent, backminsterfullerenol cancer-fighting agent.

Проведено DFT-моделирование электронных структур содержащих холестерин радионуклидных агентов (кластерных карборановых систем (орто-1, мета-2, пара-3) и производных фуллеренола), перспективных для применения в терапии онкологических заболеваний. Кластерные системы эндоэдральных производных бакминстерфуллеренолов $\tilde{\mathrm{N}}_{60}$ имеют многообещающие перспективы для применения в медицине в качестве радионуклидных наноразмерных изотопсодержащих (Fe 10a, Y 10b, Re 10c, Po 10d, Rn 10е) противораковых агентов. В соответствии с данными стабильности кластеров, полученных с использованием DFT вычислений, оценена возможность их реальной практической реализации.

Квантово-хімічне моделювання електронних структур, які містять холестерин радіонуклідних агентів. Е.А. Дікусар, В.М. Зеленовсъкий, А.Л. Пушкарчук, Д.А. Рудаков, В.И. Поткин, С.Ю. Кілін, А.Г. Солдатов, С.А. Кутень.

Проведено DFT-моделювання електронних структур які містять холестерин радіонуклідних агентів (кластерних карборанових систем (орто-1, мета-2, пара-3) і похідних фуллеренола), перспективних для застосування у терапії онкологічних захворювань. Кластерні системи ендоедральних похідних бакмінстерфуллеренолов $\mathrm{C}_{60}$ мають багатообіцяючі перспективи для застосування в медицині як радіонуклідні нанорозмірні ізотоповміщуючі (Fe 10a, Y 10b, Re 10c, Po 10d, Rn 10e) протиракові агенти. Відповідно до даних стабільності кластерів, отриманих з використанням DFT обчислень, оцінена можливість їх реальної практичної реалізації. 


\section{Introduction}

One of the commonly used cancer therapy method consists in the tumor cells irradiation by high energy proton or neutron dose to a well-defined target with little or no fractionation [1]. Nowadays the new modern technologies of tumor treatments are intensively introduced in clinical practice of radiation oncology: radiological destroying tumors by introducing the relevant short-lived radionuclides $\left(\mathrm{Y}^{90}, \mathrm{Zr}^{95}, \mathrm{Fe}^{59}\right.$, $\mathrm{In}^{114^{*}}, \mathrm{Eu}^{147}, \mathrm{Eu}^{148}, \mathrm{Eu}^{155}, \mathrm{Tm}^{170}, \mathrm{Re}^{188}$, $\mathrm{Po}^{210}, \mathrm{Rn}^{222}, \mathrm{U}^{230}, \mathrm{Pu}^{237}, \mathrm{Cm}^{240}, \mathrm{Cm}^{241}$, $\mathrm{Es}^{253}$ ), which are used in the isotopic medicine. The binary (or neutron capture) therapy is a technology that was designed for the selective action on malignant neoplasm. It uses the tumor-tropic drugs that contain nonradioactive nuclides $\left(\mathrm{B}^{10}, \mathrm{Cd}^{113}, \mathrm{Gd}^{157}\right.$, etc.) [2]. The triadic therapy is consistent placement in a body the combination of two or more tumor-tropic tissue components that are individually inactive and harmless. These components are able to be selectively accumulated in tumors. They join each other in chemical interaction and destroy the tumor neoplasm under certain sensitizing external influences [3].

The designing and synthesis of the new boron-organic compounds [4] that can be used in the binary oncological diseases therapy [2] is very perspective. In order to avoid the biological incompatibility these compounds should contain some natural fragments, for example cholesterol [5].

This work presents the results of quantum-chemical DFT simulation [6] of the electron structure and construction of cholesterol containing cluster systems of carborane and fullerenol derivatives with aim to develop the new radionuclide nanosized anticancer agents [7-12].

\section{Experimental}

Synthesis of $\mathrm{B}^{10}$-riched cholesterol esters of $o-, \quad m-$, and $p$-carborane-C-carboxylic acids 1-3 [11] is intensive labor and high cost task. Recently we synthesized cholesterol esters of $o$-carborane-C-carboxylic acid 1, m.p. $=101-102^{\circ} \mathrm{C}$ [13], and $m$-carboraneC-carboxylic acid 2, m.p. $=162-163^{\circ} \mathrm{C}$ [14], which have native relation of boron isotopes. Corresponding derivative of $p$-carborane-C-carboxylic acid 3 (Fig. 1-4) has not been synthesized yet caused by high cost of precursors. Characteristics of their electronic structure and relative stability are very important parameters that determinate these compound behaviors in biological media.

In order to estimate stability of isomeric cholesterol ester of $o$-, $m$-, and $p$-carboraneC-carboxylic acids 1-3 and to study their electronic structure and construction the non-empiric quantum chemical calculations of these compounds were carried out by

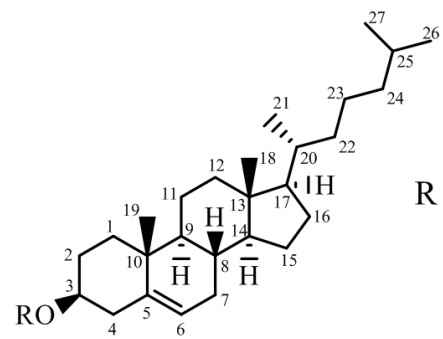

2a
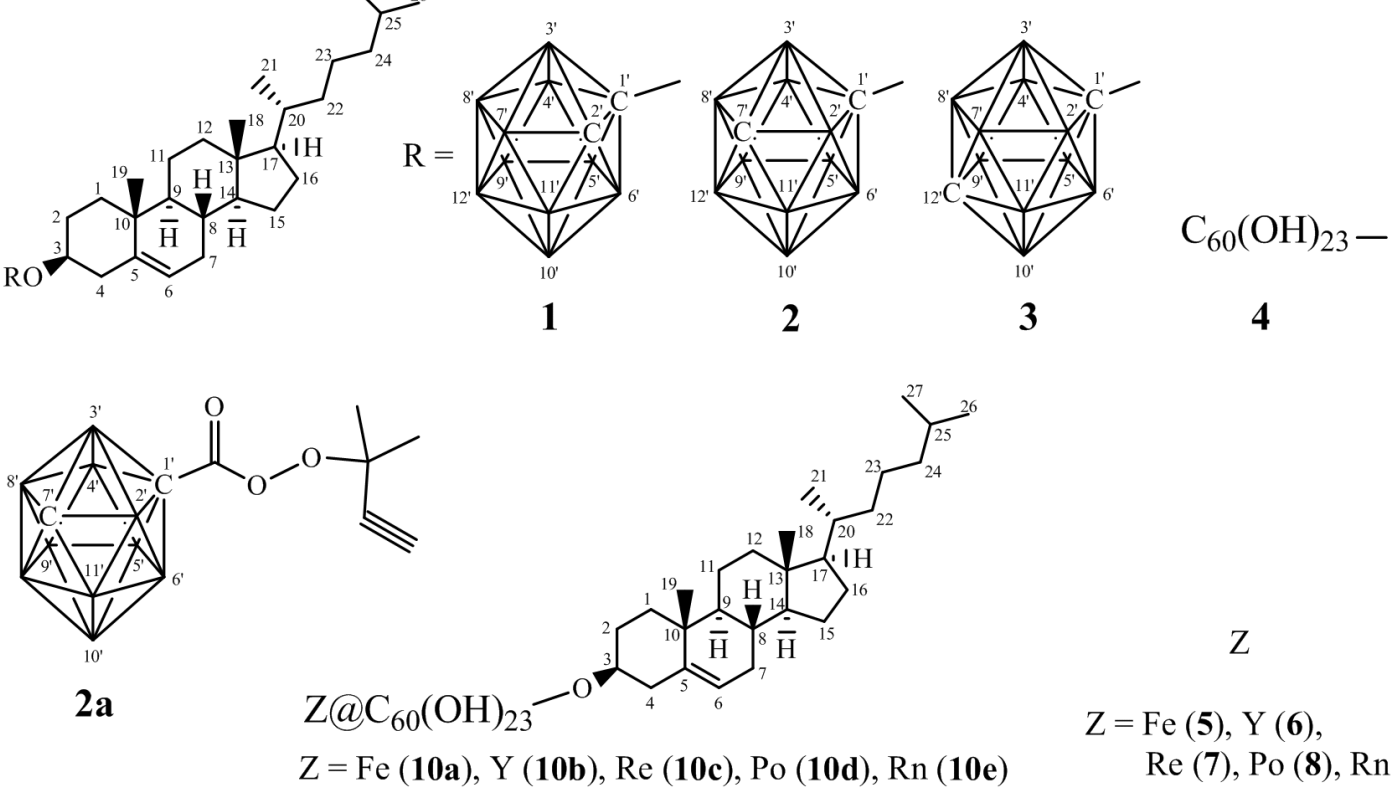

$$
\begin{gathered}
Z \\
Z=F e(5), Y(6), \\
\quad \operatorname{Re}(\mathbf{7}), \operatorname{Po}(\mathbf{8}), \operatorname{Rn}(\mathbf{9})
\end{gathered}
$$

Fig. 1. Synthesized cholesterol esters of carborane-C-carboxylic acids 1-3, peroxide 2a, fullerenol 4 and DFT simulated backminsterfullerenol derivatives $Z \cong C_{60}(O H)_{23} O$-cholesterol $[Z=F e(10 a), Y$ (10b), Re (10c), Po (10d), Rn (10e)]. 


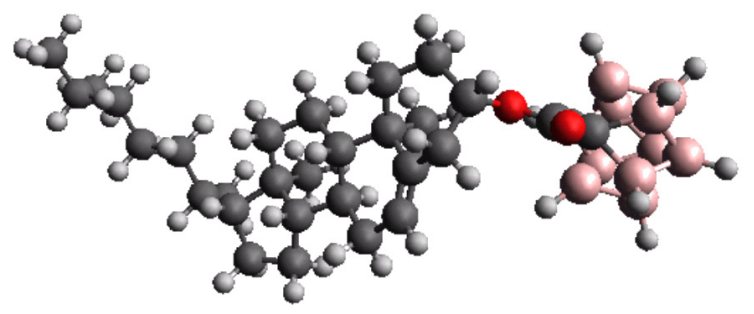

Fig. 2. DFT B3LYP1/6-31G(d) model of cholesterol ester of $\boldsymbol{o}$-carborane-C-carboxylic acid $\mathbf{1}$.

DFT method on the level of B3LYP/MIDI theory following the GAMESS software [15]. Full energy of the systems, energy of HOMO, LUMO and dipole moments computed by the DFT method for compounds 1-3 are presented in Table.

\section{Results and discussion}

Computed unit cell parameters of the $m$-carborane-C-carboxylic fragment of cholesterol ester 2 (Fig. 3) are in well agreement with the X-ray data of 3-methyl3-[1,7-dicarba-closo-dodecaboran(12)-1-oilper oxy] but-1-ine 2a, which has the same fragment [16]. In particular, the bridge $\mathrm{C}-\mathrm{C}$ bond length in the $m$-carborane-C-carboxylic fragment calculated by the DFT located between $m$-carborane- $\mathrm{C}$ - and $-\mathrm{C}=\mathrm{O}$ groups is $0.1525 \mathrm{~nm}$ for compound 2. According to the X-ray data the same bridge $\mathrm{C}-\mathrm{C}$ bond length in peroxide $2 \mathrm{a}$ is $0.1518(6) \mathrm{nm}$ [16].

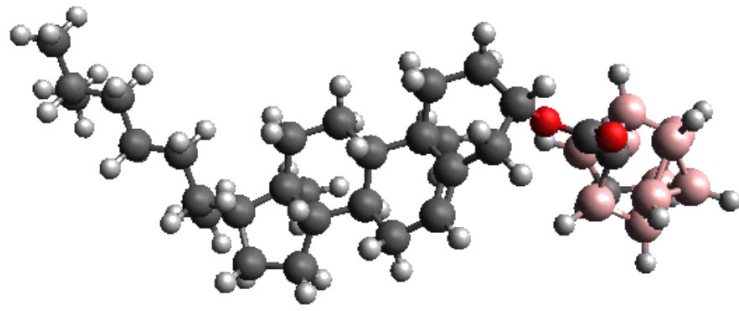

Fig. 3. DFT B3LYP1/6-31G(d) model of cholesterol ester of $m$-carborane-C-carboxylic acid 2.

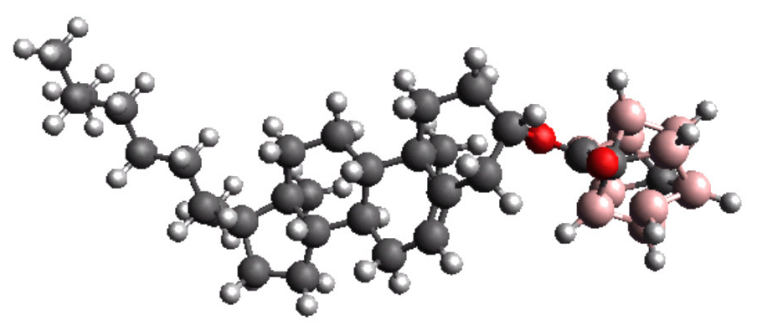

Fig. 4. DFT B3LYP1/6-31G(d) model of cholesterol ester of $p$-carborane-C-carboxylic acid $\mathbf{3}$.

Comparison of the calculated full energy values of the compounds 1-3 (see Table) shows that among the cholesterol esters of $o-, m$-, and $p$-carborane-C-carboxylic acids 1-3 the compounds 3 is the most energetically favorable.

Dipole moments, which characterize distribution asymmetry of positive and nega-

Table. Total energies $\left(E_{t o t}\right)$ of systems (I-XIV), energies HOMO ( $\left.E_{\text {HOMO }}\right)$ and LUMO $\left(E_{L U M O}\right)$, and dipole moments. Interaction estimation $\left(\Delta E_{\text {int }}\right)$ calculated by DFT method

\begin{tabular}{|c|c|c|c|c|c||}
\hline No. & $E_{\text {tot }}$, a.u. & $E_{H O M O}$, a.u. & $E_{L U M O}$, a.u. & Dipole moments, D & $\Delta E_{\text {int }}, \mathrm{kJ} / \mathrm{mole}$ \\
\hline $\mathbf{1}$ & -1576.049067 & -0.2371 & 0.0183 & 7.00 & - \\
$\mathbf{2}$ & -1576.072327 & -0.2311 & 0.0734 & 5.07 & - \\
$\mathbf{3}$ & -1576.077013 & -0.2274 & 0.0268 & 2.39 & - \\
$\mathbf{4}$ & -5130.939156 & -0.0915 & -0.0236 & 3.89 & - \\
$\mathbf{5}$ & -1258.130847 & -0.1078 & 0.0493 & 0 & - \\
$\mathbf{6}$ & -3321.291999 & -0.1598 & -0.1205 & 0 & - \\
$\mathbf{7}$ & -15743.255420 & -0.0948 & -0.0526 & 0 & - \\
$\mathbf{8}$ & -20624.988237 & -0.2134 & 0.0463 & 0 & -177.2 \\
$\mathbf{9}$ & -21813.044758 & -0.3204 & 0.1530 & 0 & -139.1 \\
10a & -6389.137488 & -0.1040 & -0.0306 & 8.87 & -294.9 \\
10b & -8452.284126 & -0.1005 & -0.0561 & 5.08 & 207.4 \\
10c & -20874.306882 & -0.0749 & -0.0281 & 4.02 & 125.6 \\
\hline 10d & -25755.848398 & -0.0816 & -0.0294 & 8.57 & 3.90 \\
10e & -26943.936066 & -0.0888 & -0.0250 & 0 & - \\
\hline
\end{tabular}


tive charges of electrically neutral molecules of the cholesterol esters of $o-, m-$, and $p$-carborane-C-carboxylic acids 1-3, gradually decreases from $o$-isomer to the $p$-one (see Tabl. 1). So we can conclude that among the cholesterol esters 1-3 the compound $\mathbf{1}$ is more polar than compound $\mathbf{2}$ and compound $\mathbf{3}$ is less polar than others. In biological media all "guest" molecules undergo fermentative attack by polar peptides (hydrolysis, alcoholysis, ammonolysis etc.). We guess that the ester 1 will be more stable in biological liquids than the others and the ester 3 will be the most unstable.

Modelling of the electronic structure and construction of endohedral buckminsterfullerenol clusters $\mathrm{Z} @ \mathrm{C}_{60}(\mathrm{OH})_{23} \mathrm{O}$-cholesterol $\mathbf{1 0 a}-\mathbf{e}$ was performed for $Z=\mathrm{Fe}$ (10a), Y (10b), Re (10c), Po (10d), Rn (10e) (Fig. 5), "empty" fullerenol cluster is the monoester of fullerenol and cholesterol $\mathrm{C}_{60}(\mathrm{OH})_{23} \mathrm{O}$-cholesterol 4 , and isolated atoms are incorporated components: $\mathrm{Fe}(5), \mathrm{Y}(6)$, Gd (7), Po (8), Rn (9). The necessity of preliminary investigations by computer modelling is caused by the intensive labor and high cost [17]. The non-empirical quantum chemical calculations of the compounds (4, 10a-e) were carried out by the DFT method on the level of B3LYP/MIDI theory following the GAMESS software [15, 18]. Total energy of systems, computed by the DFT method for compounds (4-10e), the energy of the HOMO, LUMO and dipole moments are presented in Table.

The quantum-chemical simulation allows making conclusions about the stability and the possible existence of endohedral fullerene

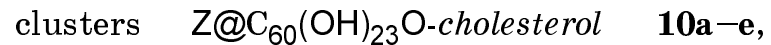
which electron density distribution is shown in Fig. 5 for $Z=R n$. According to the quantum chemical calculation data (see Table) the interaction energy of endohedral clusters $\mathbf{1 0 a}-\mathbf{e}$, which can be calculated by the following formula (1):

$$
\begin{gathered}
\Delta E \int(\mathbf{1 0 a}-\boldsymbol{e})= \\
=E_{t o t}(\mathbf{1 0 a}-\boldsymbol{e})-\left[E_{t o t}(\mathbf{4})+E_{t o t}(\mathbf{5}-\mathbf{9})\right]
\end{gathered}
$$

shows that thermodynamic stability $[19,20]$ of the endohedral fullerenol cluster systems $\mathrm{C}_{60} \quad \mathbf{1 0 a}-\mathbf{e}$ differs by $\pm 126-295 \mathrm{~kJ} / \mathrm{mole}$ from the total energy sum of "empty" fullerenol cluster (IV) and isolated molecules Z 5-9.

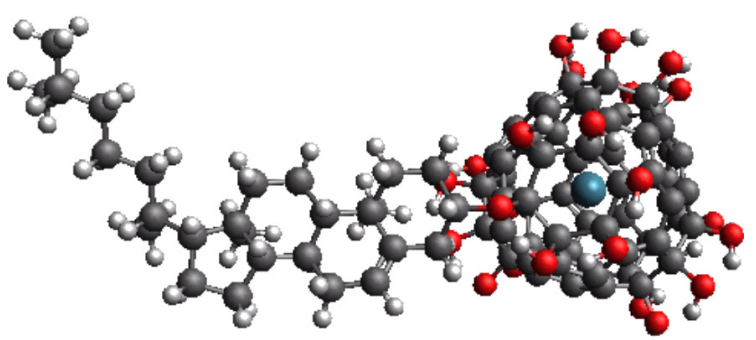

Fig. 5. DFT B3LYP/MIDI model of $\mathrm{Rn} @ \mathrm{C}_{60}(\mathrm{OH})_{23} \mathrm{O}$-cholesterol 10e.

\section{Conclusions}

Cluster systems of endohedral backminsterfullerenol $\mathrm{C}_{60}$ derivatives $(\mathbf{1 0 a}-\mathbf{e})$ have the promise perspectives in medical application as radionuclide $(\mathrm{Fe}, \mathrm{Y}, \mathrm{Re}, \mathrm{Po}, \mathrm{Rn}$ isotope contained) nanosized anticancer agents. According to the cluster $(\mathbf{1 0 a}-\mathbf{e})$ stability data obtained by DFT calculation there is a possibility of their real practical embodiment.

Acknowledgments. Support by the "Convergence" and "Nanotech" national scientific programs, Belarus, is gratefully acknowledged. This work was performed using computational facilities of joint computational cluster of SSI "Institute for Single Crystals" and Institute for Scintillation Materials of National Academy of Sciences of Ukraine incorporated into Ukrainian National Grid.

\section{References}

1. 1. P.Mayles, A.Nahum, J.C.Rosenwald, Handbook of Radiation Therapy Physics: Theory and Practice, Taylon \& Francis (2007).

2. N.S.Hosmane, A.Jmaquire, Y.Zhu, Boron and Gadolinium Neutron Capture Therapy for Cancer Treatment, World Scientific Publishing Co. Pte. Ltd. (2012).

3. A.V.Vorst, A.Rosen, Y.Kotsuka, RF/Microwave Interaction with Biological Tissues, IEEE Press, Wiley Interscience, A John Wiley \& Sons., Inc., Publ. (2006).

4. R.N.Grimes, Carboranes, 2th ed., Acad. Press is an imprint of Elsevier Inc., Amsterdam, Boston, Heidelberg, London, New York, Oxford, Paris, San Diego, San Francisco, Singapore, Sydney, Tokyo (2011).

5. N.B.Myant, The Biology of Cholesterol and Related Steroids, William Heinemann Medical Book Ltd., London (1981).

6. S.K.Ghosh, P.K.Chattaraj, Concepts and Methods in Modern Theoretical Chemistry. Atoms, Molecules and Clusters, CRC Press (2013). 
7. E.A.Dikusar, V.M.Zelenkovskii, A.L.Pushkarchuk et al., in: Proc. of the 21-th Annual Seminar (NPCS'2014), Minsk (2014), p.20.

8. E.A.Dikusar, V.M.Zelenkovski, V.I.Potkin et al., in: Proc. of Intern. Conf. Nanomeeting, 2013, Physics, Chemistry and Application of Nanostructures. Rev. and Short Notes. Minsk, Belarus (2013), p.324.

9. E.Dikusar, V.Zelenkovski, V.Potkin et al., Nonlinear Phenomena in Complex Systems, 14, 356 (2011).

10. E.A.Dikusar, A.L.Pushkarchuk, V.M.Zelenkovski et al., Book of Abstr. $5^{\text {th }}$ Intern. Symp. "Methods and Applications of Computational Chemistry", Kharkiv, Ukraine (2013), p.99.

11. E.Dikusar, V.Potkin, V.Zelenkovskii et al., Fundamental and Applied NanoElectroMagnetics (FANEM'12), 25th anniversary of the Res. Inst.for Nucl. Probl. BSU, Conf. Proc., Belarussian State University, Minsk, Belarus (2012), p.15.
12. E.A.Dikusar, V.M.Zelenkovski, V.I.Potkin et al., Theor. Exp. Chem., 46, 213 (2010).

13. E.A.Dikusar, N.G.Kozlov, V.I.Potkin et al., Chem. Natural Comp., 42, 539 (2006).

14. E.A.Dikusar, V.I.Potkin, N.G.Kozlov et al., Russ.J.Organ. Chem., 44, 1305 (2008).

15. M.W.Shmidt, K.K.Baldridge, J.A.Boatz et al., J.Comput.Chem., 14, 1347 (1993).

16. A.S.Lyakhov, L.S.Ivashkevich, A.P.Yuvchenko et al., Crystallogr.Rep., 46, 971 (2001).

17. M.A.Orlova, T.P.Trofimova, A.P.Orlov et al., British J. Medic. Med. Res., 3, 1731 (2013).

18. S.Huzinaga, J.Andzelm, M.Klobukowski, Gaussian Basis Sets for Molecular Calculations, Elsevier, Amsterdam, (1984).

19. S.I.Sandler, Chemical, Biochemical and Engineering Thermodynamics, A John Wiley \& Sons., Inc., Publ. (2006).

20. Y.Demerel, Nonequilibrium Thermodynamics, 3rd ed., Elsevier Science (2014). 